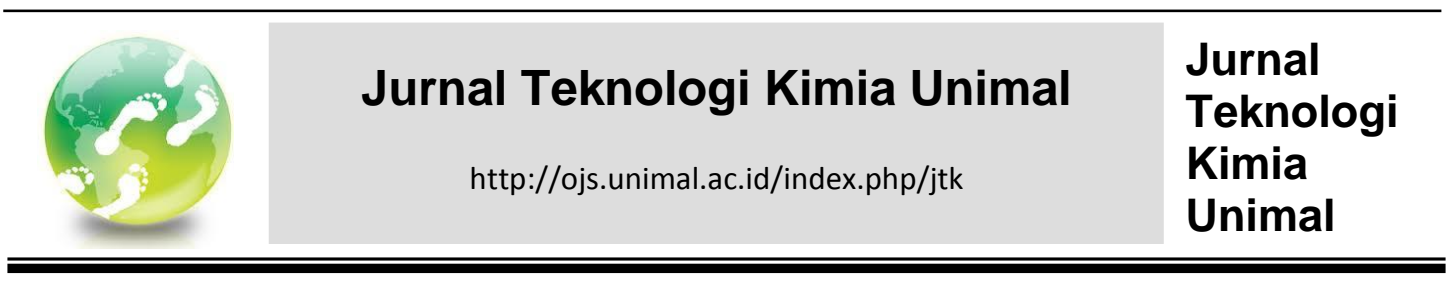

\title{
Analisa Profil Aliran Fluida Cair dan Pressure Drop pada Pipa L menggunakan Metode Simulasi Computational Fluid Dynamic (CFD)
}

\author{
Jalaluddin, Saiful Akmal, Nasrul Za, Ishak \\ Jurusan Teknik Kimia, Fakultas Teknik, \\ Universitas Malikussaleh \\ Aceh, Indonesia
}

\begin{abstract}
Abstrak
Sistem perpipaan adalah suatu sistem yang banyak digunakan untuk memindahkan fluida, baik cair, gas, maupun campuran cair dan gas dari suatu tempat ke tempat yang lain, pipa memiliki berbagai ukuran dan bentuk penampang. Penurunan tekanan (Pressure drop) aliran di dalam pipa sangat penting untuk diketahui guna merancang sistem perpipaan. Kekasaran pipa, panjang pipa, diameter pipa, jenis fluida, kecepatan dan bentuk aliran adalah hal yang sangat terkait dengan penurunan tekanan (Pressure drop). Penelitian ini bertujuan untuk Mengetahui hasil analisa aliran fluida yang terdapat dalam pipa L, Mengetahui jenis pola aliran yang terbentuk di dalam pipa L, dan Mengetahui berapa besar Pressure drop yang terjadi. Penelitian ini dilakukan dengan memvariasikan laju alir dan jenis fluida.. Pada penelitian ini dengan laju aliran 14 ton/jam menggunakan fluida air diperoleh bilangan reynold sebesar 35.252,5, penurunan tekanan $\Delta \mathrm{P}$ sebesar 2,78801 Bar. Pada fluida amonia diperoleh bilangan reynold sebesar 160.720, penurunan tekanan $\Delta \mathrm{P}$ sebesar 0,28127 Bar. Pada fluida solar diperoleh bilangan reynold sebesar 16.999,2, penurunan tekanan $\Delta \mathrm{P}$ sebesar 3,16401 Bar. Pada fluida bensin diperoleh bilangan reynold sebesar 90.199,7, penurunan tekanan $\Delta \mathrm{P}$ sebesar 1,84231 Bar. Pada fluida etilen glikol diperoleh bilangan reynold sebesar 1.652,26, penurunan tekanan $\Delta \mathrm{P}$ sebesar 4,49503 Bar Dari hasil tersebut dimana semakin besar viskositas dari jenis fluida maka semakin tinggi penurunan tekanan (pressure drop) dan semakin kecil nilai Reynol numbernya.
\end{abstract}

\section{Pendahuluan}

Computational Fluid Dynamics (CFD) merupakan salah satu cabang dari mekanika fluida yang menggunakan metode numerik dan algoritma untuk menyelesaikan dan menganalisa permasalahan yang berhubungan dengan aliran fluida. Sejarah CFD mulai dikenal pada tahun 60 - 70an yang memakai konsep CFD yang menggunakan reaksi kimia, namun karena perkembangan jaman membuat aplikasi CFD ini dibutuhkan dalam berbagai aplikasi lain. Contoh nya 
seperti aplikasi CAD yang menggunakan konsep CFD untuk menganalisa stress pada disign yang dibuat. Penggunaan CFD di dunia industri relatif baru, pertama kali digunakan sekitar tahun 1990-an pada industri penerbangan.

Mekanika fluida merupakan ilmu yang mempelajari keseimbangan dan gerakan zat cair maupun gas, serta gaya tarik dengan benda-benda disekitarnya atau yang dilalui saat mengalir. Fluida adalah zat yang dapat bergerak ketika dikenai gaya. Fluida dapat berubah bentuk dan bersifat tidak permanen. Fluida membentuk berbagai jenis benda padat sesuai dengan bentuk benda yang dilewatinya (Al-Shemmeri, 2012).

\section{Landasan Teori}

\section{Computational Fluid Dynamics (CFD)}

Computational Fluid Dynamics (CFD) merupakan analisa sistem yang mencakup aliran fluida, perpindahan panas, dan fenomena yang terkait. Seperti reaksi kimia dengan menggunakan simulasi berbasis komputer (numeric).

Kontrol-kontrol penghitungan ini beserta kontrol- kontrol penghitungan lainnya merupakan pembagian ruang yang disebut tadi atau meshing. Nantinya, pada setiap titik kontrol penghitungan akan dilakukan penghitungan oleh aplikasi dengan batasan domain dan boundary condition yang telah ditentukan. Prinsip inilah yang banyak dipakai pada proses penghitungan dengan menggunakan bantuan komputasi komputer. Contoh lain penerapan prinsip ini adalah Finite Element Analysis (FEA) yang digunakan untuk menghitung tegangan yang terjadi pada benda solid. (Al-Shemmeri, 2012)

\section{Fluida}

Fluida adalah zat yang dapat bergerak ketika dikenai gaya. Fluida dapat berubah bentuk dan bersifat tidak permanen. Fluida membentuk berbagai jenis 
benda padat sesuai dengan bentuk benda yang dilewatinya (Al-Shemmeri, 2012). Karakteristik aliran fluida meliputi tekanan statis, tekanan dinamis, total tekanan, kecepatan fluida dan tegangan geser.

Di daerah yang pengaruh gesekan dinding kecil, tegangan geser dapat diabaikan dan perilakunya mendekati fluida-ideal, yaitu incompresible dan mempunyai viskositas 0.Aliran fluida ideal yang demikian disebut aliran potensial. Pada aliran potensial berlaku prinsip-prinsip mekanika Newton dan hukum kekekalan massa. Aliran potensial mempunyai 2 ciri pokok:

1. Tidak terdapat sirkulasi ataupun pusaran sehingga aliran potensial itu disebut aliran irotasional.

2. Tidak terjadi gesekan sehingga tidak ada disipasi (pelepasan) dari energi mekanik menjadi kalor

\section{Bilangan Reynold}

Bilangan Reynolds digunakan untuk menentukan sifat pokok aliran, apakah aliran tersebut laminar, transisi atau turbulen serta letaknya pada skala yang menunjukkan pentingnya secara relatif kecenderungan turbulen berbanding dengan laminar ditunjukkan dalam persamaan berikut:

$$
\mathrm{N}_{\mathrm{re}}=\frac{D \cdot D \cdot p}{\mu}
$$

Pada fluida air, suatu aliran diklasifikasikan laminar apabila aliran tersebut mempunyai bilangan Reynold (Re) kurang dari 2300. Untuk aliran transisi berada pada bilangan $2300<\operatorname{Re}<4000$, disebut juga sebagai bilangan Reynold kritis.Sedangkan untuk aliran turbulen mempunyai bilangan Reynolds lebih dari 4000.

\section{Rapat Jenis (Density)}

Density atau rapat jenis $(\rho)$ sutau zat adalah ukuran bentuk konsentrasi zat tersebut dan dinyatakan dalam massa per satuan volume, sifat ini ditentukan 
dengan cara menghitung nisbah (ratio) massa zat yang terkandung dalam suatu bagian tertentu terhadap volume bagian tersebut. Hubungannya dapat dinyatakan dalam persamaan berikut:

$$
\rho=\frac{m}{V}
$$

\section{Viskositas}

Viskositas fluida merupakan ukuran ketahanan sebuah fluida terhadap deformasi atau perubahan bentuk. Viskositas dipengaruhi oleh temperatur, tekanan, kohesi dan laju perpindahan momentum molekulernya. Viskositas zat cair cenderung menurun dengan seiring bertambahnya kenaikan temperatur hal ini disebabkan gaya - gaya kohesi pada zat cair bila dipanaskan akan mengalami penurunan dengan semakin bertambahnya temperatur pada zat cair yang menyebabkan berturunnya viskositas dari zat cair tersebut. Viskositas dibedakan atas dua macam, yaitu viskositas kinematik dan viskositas dinamik atau viskositas mutlak.

\section{Jenis-Jenis Aliran}

\section{Laminer}

Aliran laminer didefinisikan sebagai aliran dengan fluida yang bergerak dalam lapisan-lapisan atau lamina-lamina dengan satu lapisan meluncur secara lancar. Aliran laminer ini mempunyai nilai bilangan Reynoldsnya kurang dari 2000.

\section{Transisi}

Aliran transisi merupakan aliran peralihan dari aliran laminer ke aliran turbulen. aliran turbulen mempunyai nilai bilangan Reynoldsnya antara 2000 sampai dengan 4000.

3. Turbulen 
Aliran turbulen didefinisikan sebagai aliran yang dimana pergerakan dari partikel-partikel fluida sangat tidak menentu karena mengalami percampuran serta putaran partikel antar lapisan, yang mengakibatkan saling tukar momentum dari satu bagian fluida ke bagian fluida yang lain dalam skala yang besar di mana nilai bilangan Reynoldsnya lebih besar dari 4000 .

\section{Debit Aliran Fluida}

Debit aliran fluida merupakan rumus yang digunakan untuk menghitung kecepatan aliran fluida, yaitu diperlihatkan dalam persamaan

$$
\mathrm{Q}=\frac{V}{t}
$$

Kemudian dari persamaan kontinuitas akan didapatkan rumus seperti yang ditunjukkan dalam persamaan

$$
\mathrm{Q}=\mathrm{A} \cdot \mathrm{V}, \operatorname{dimana} \mathrm{A}=\frac{1}{4} \pi \mathrm{D}^{2}
$$

maka kecepatan aliran dalam suatu penampang adalah :

$$
\mathrm{V}=\frac{\mathrm{Q}}{\mathrm{A}}
$$

\section{Persamaan Kontinuitas}

Persamaan kontinuitas mengatakan hubungan antara kecepatan fluida yang masuk pada suatu pipa terhadap kecepatan fluida yang keluar(White.1988). Hubungan tersebut dinyatakan dengan :

$$
\mathrm{Q}=\mathrm{A} \mathrm{V}
$$

Debit adalah besaran yang menyatakan volume fluida yang mengalir tiap satuan waktu.

$$
\mathrm{Q}=\mathrm{V} / \mathrm{t}
$$

Jika disubtitusikan persamaan 6 dan 7 maka akan dihasilkan persamaan:

$$
\mathrm{v}=\frac{\mathrm{V}}{\mathrm{t} \cdot \mathrm{A}}
$$


Jika fluida bergerak dalam pipa yang mengalir dengan luas penampang yang berbeda maka volume yang mengalir(Tipler.1998) :

$\mathrm{V}=\mathrm{A} \cdot \mathrm{v} \cdot \mathrm{t}$

$\mathrm{A}_{1} \cdot \mathrm{v}_{1} \cdot \mathrm{t}_{1}=\mathrm{A}_{2} \cdot \mathrm{v}_{2} \cdot \mathrm{t}_{2}$

\section{Persamaan Bernoulli}

Persamaan Bernoulli ideal adalah alirannya konstan sepanjang lintasan dan mengabaikan segala kerugian yang terjadi dalam lintasan fluida.

$\frac{p}{p}+\frac{V^{2}}{2}+g z=$ konstan

\section{Pressure Drop}

Pressure drop adalah istilah yang digunakan untuk menggambarkan penurunan tekanan dari satu titik di dalam pipa atau aliran air. "Penurunan Tekanan" adalah hasil dari gaya gesek pada fluida seperti yang mengalir melalui tabung. Gaya gesek disebabkan oleh resistensi terhadap aliran. Pada aliran satu fase, pressure drop dipengaruhi oleh Reynold number yang merupakan fungsi dari viskositas, densitas fluida dan diameter pipa (Deslia,2011).

\section{Gesekan dalam pipa}

Salah satu komponen penyambungan dalam sistem perpipaan adalah pipe bend (pipa lengkung) atau elbow. Pipe bend berfungsi untuk membelokkan arah aliran fluida didalam pipa. Namun pipe bend lebih sulit untuk dianalisa karena permukaannya menjadi oval dibawah pembebanan momen bending. Hal ini menyebabkan pipe bend memiliki fleksibilitas yang lebih besar dibandingkan dengan pipa lurus yang sama ukuran dan jenis materialnya. Lebihnya fleksibilitas ini menjadikan pipe bend berfungsi sebagai penyerap ekspansi thermal. Dengan berbagai karakteristik tersebut, pipe bend menjadi komponen yang sangat penting 
di dalam sistem perpipaan dan memerlukan berbagai macam pertimbangan dalam proses perancangannya (Mc.Cabe.1985).

\section{Jenis-jenis fluida yang digunakan}

1. Air

2. Amonia

3. Solar

4. Bensin

5. Etilen glikol

\section{Aliran Fluida Dalam Saluran Tertutup (Pipa)}

Pipa adalah saluran tertutup yang biasanya berpenampang lingkaran yang digunakan untuk mengalirkan fluida dengan tampang aliran penuh. Fluida yang di alirkan melalui pipa bisa berupa zat cair atau gas dan tekanan bisa lebih besar atau lebih kecil dari tekanan atmosfer.

\section{Sistem Perpipaan}

Sistem perpipaan adalah suatu sistem yang banyak digunakan untuk memindahkan fluida, baik cair, gas, maupun campuran cair dan gas dari suatu tempat ke tempat yang lain. Penurunan tekanan terjadi akibat adanya turbulensi aliran yang akan menimbulkan gesekan besar pada dinding pipa sehingga akan menimbulkan head losses yang besar.

\section{Macam-macam Sambungan Perpipaan}

Sambungan perpipaan dapat dikelompokkan sebagai berikut:

1. Sambungan dengan menggunakan pengelasan

2. Sambungan dengan menggunakan ulir 
Selain sambungan seperti diatas terdapat pula penyambungan khusus dengan menggunakan pengeleman (perekatan) serta pengkleman (untuk pipa plsatik dan pipe fiber glas). Pada pengilangan umumnya pipa bertekanan rendah dan pipa dibawah 2" sajalah yg menggunakan sambungan ulir.

\section{Tipe sambungan cabang}

Tipe sambungan cabang (branch connection)dapat dikelompokkan sbb:

1. Sambungan langsung (stub in)

2. Sambungan dengan menggunakan fittings (alat penyambung)

3. Sambungan dengan menggunakan flanges (flens-flens).

Tipe sambungan cabang dapat pula ditentukan pada spesifikasi yg telah dibuat sebelum mendesain atau dapat pula dihitung berdasarkan perhitungan kekuatan, kebutuhan, dengan tidak melupakan faktor efektifitasnya.

\section{Kehilangan-kehilangan Energi pada Sistem Perpipaan}

\section{Kehilangan Longitudinal (Longitudinal Losses)}

Kehilangan longitudinal yang disebabkan oleh gesekan sepanjang lingkaran pipa. Gambar 1 menunjukkan nilai faktor gesekan pada diagram Moody.

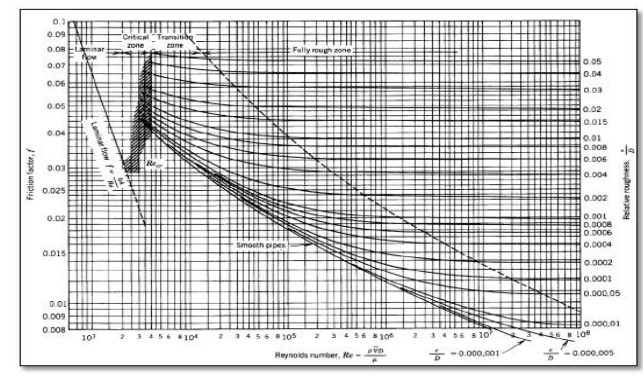

Gambar 1 Diagram Moody

2. Kehilangan Lokal (Local Losses) 
Kerugian lokal adalah kerugian head yang disebabkan karena sambungan, belokan, katup, pembesaran/pengecilan penampang, sehingga oleh Bakti (2012) yang dapat dilihat pada persamaan berikut:

$\mathrm{h}_{1}=\mathrm{h}_{0}+\mathrm{h}_{\mathrm{b}}+\mathrm{h}_{\mathrm{c}}$

\section{Simulasi Menggunakan Software Computational Fluid Dynamics (CFD)}

Simulasi adalah tiruan dari sebuah sistem dinamis dengan menggunakan model komputer yang digunakan untuk melakukan evaluasi dan meningkatkan kinerja sistem. Definisi lain dari simulasi:

1. Cara untuk mereproduksi kondisi situasi, dengan menggunakan model, untuk mempelajari, menguji, pelatihan, dll.

2. Pemodelan dari sebuah proses atau sistem dimana model meniru respon dari sistem nyata untuk setiap kejadian yang terjadi setiap saat.

\section{Computational Fluid Dynamics (CFD)}

Computational Fluid Dynamics (CFD) adalah metode perhitungan dengan sebuah control dimensi, luas dan volume dengan memanfaatkan bantuan komputasi komputer untuk melakukan perhitungan pada tiap-tiap elemen pembaginya. Prinsipnya adalah suatu ruang yang berisi fluida yang akan dilakukan penghitungan dibagi-bagi menjadi beberapa bagian, hal ini sering disebut dengan sel dan prosesnya dinamakan meshing. Bagian-bagian yang terbagi tersebut merupakan sebuah kontrol penghitungan yang akan dilakukan adalah aplikasi.

\section{Autodesk Inventor}

Autodesk Inventor merupakan program yang dirancang khusus untuk keperluan bidang teknik seperti desain produk, desain mesin, desain mold, desain konstruksi, atau keperluan teknik lainnya. Autodesk Inventor adalah program 
pemodelan solid berbasis fitur parametrik, artinya semua objek dan hubungan antargeometri dapat dimodifikasi kembali meski geometrinya sudah jadi, tanpa perlu mengulang lagi dari awal.

\section{Autodesk Simulation CFD}

Autodesk Simulation CFD merupakan program simulasi aliran fluida dan termal untuk membantu menganalisa aliran fluida dan pergantian panas di dalam maupun di luar bangunan. Adapun faktor-faktor seperti tampilan estetis, kenyamanan termal, kualitas udara dalam ruang, dan kebutuhan keamanan menjadi pertimbangan. Autodesk Simulation CFD juga menyajikan simulasi yang nyata untuk membantu dalam menciptakan desain yang hemat energi dan berkelanjutan.

\section{Metodologi Penelitian}

Penelitian ini bersifat komputasi numerik dimana penelitian awalnya dimulai dengan penggambaran geometri alur pipa berbentuk L di unit ammonia cair dengan menggunakan software Autodesk Inventor kemudian untuk kalkulasi numeriknya menggunakan software Autodesk Simulation CFD.

\section{Tempat dan Waktu penelitian}

Penelitian ini dilakukan di Laboratorium modeling Jurusan Teknik Kimia dan ruang belajar mahasiswa serta di tempat kediaman mahasiswa itu sendiri.

\section{Variabel Penelitian}

Adapun yang menjadi variabel tetap dalam penelitian ini adalah panjang pipa $\quad: 10 \mathrm{~m}$, jenis sambungan : sambungan langsung, jumlah belokan $: 1$, tekanan : :7,84532 bar, diameter pipa : 6 in, material pipa : stainless steel. Adapun yang menjadi variabel bebas dalam penelitian ini adalah : 
laju alir $\quad: 10,11,12,13$, dan 14 ton/jam; jenis fluida : air (water), dan amonia (liquid phase), solar (diesel fuel), bensin (gasoline), dan etilena glikol. Adapun yang menjadi variabel terikat dalam penelitian ini adalah : penurunan tekanan $(\Delta \mathrm{P})$, bilangan Reynold $\left(\mathrm{N}_{\mathrm{Re}}\right)$, dan profil aliran fluida.

\section{Prosedur Kerja}

Secara keseluruhan proses simulasi untuk penelitian ini ada 6 langkah yang sebelumnya dimulai dari pembentukan geometri dapat dilihat pada diagram alir prosedur simulasi pada Gambar 2.

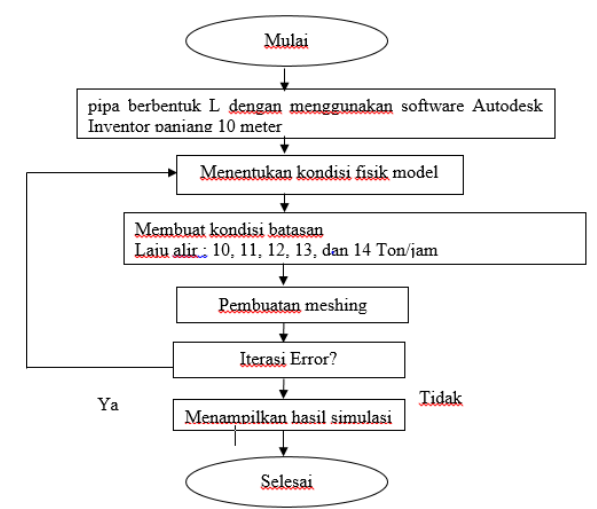

Gambar 2 Flowchart Pembuatan Geometri dan proses simulasi

\section{Penggambaran Geometri Alur Pipa Bersambung}

Hal yang perlu dilakukan pertama kali sebelum melakukan proses simulasi adalah membuat model aliran yang terjadi pada pipa L. Dalam pembuatan model menggunakan software Autodesk Invertor.

\section{Tahap Desain Permodelan Pada Autodesk Invertor}

Autodesk Invertor merupakan salah satu perangkat lunak analisis komputasi untuk membantu membuat gambar atau model untuk disimulasikan ke software Autodesk Simulation CFD. 
Pada Autodesk Invertor ini untuk mendesain gambar yang akan disimulasikan akan berbentuk gambar 3D seperti Gambar 3.

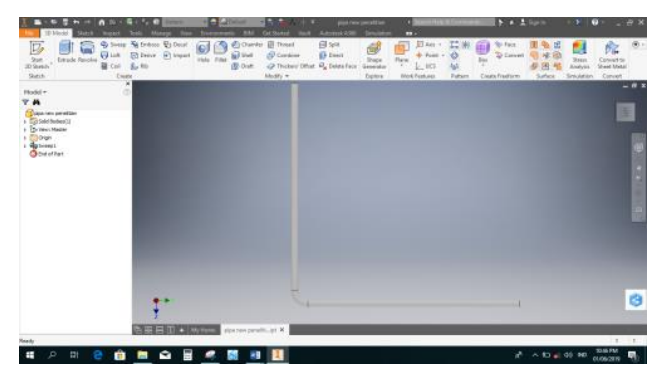

Gambar 3 Pipa $L$ pada software autodesk invertor berbentuk 3D

\section{Hasil dan Pembahasan}

\section{Hasil Penelitian}

Hasil penelitian Pada Pipa L dengan Variasi jenis fluida dan Laju alir.

\section{Tabel 1 Data Penelitian}

\begin{tabular}{|c|c|c|c|c|c|c|}
\hline Run & \begin{tabular}{|l} 
Jenis \\
Fluida
\end{tabular} & $\begin{array}{l}\text { Laju Alir } \\
\text { Ton } \text { jam }\end{array}$ & $\begin{array}{c}\text { Tekanan } \\
\text { Masulk } \\
\text { (Bar) }\end{array}$ & $\begin{array}{c}\text { Tekanan } \\
\text { Keluar } \\
\text { (Bar) } \\
\end{array}$ & $\begin{array}{c}\text { Pressure } \\
\text { Drop } \\
\text { (Bar) } \\
\end{array}$ & $\begin{array}{l}\text { Reynold } \\
\text { Number }\end{array}$ \\
\hline 1 & \begin{tabular}{|l|} 
Air \\
\end{tabular} & 10 & 7,84532 & 5,20653 & 2,63879 & $25.180,4$ \\
\hline 2 & Air & 11 & 7,84532 & 5,19894 & 2,64638 & $27.698,5$ \\
\hline 3 & Air & 12 & 7,84532 & 5,1535 & 2,69182 & \begin{tabular}{|l|}
$30.216,4$ \\
\end{tabular} \\
\hline 4 & Air & 13 & 7,84532 & 5,13263 & 2,71269 & $32.734,5$ \\
\hline 5 & Air & 14 & 7,84532 & 5,05731 & 2,78801 & $35.252,5$ \\
\hline 6 & Ammonia & 10 & 7,84532 & 7,56733 & 0,27799 & 114.800 \\
\hline 7 & Ammonia & 11 & 7,84532 & 7,56563 & 0,27969 & 126.280 \\
\hline 8 & Ammonia & 12 & 7,84532 & 7,56503 & 0,28029 & 137.759 \\
\hline 9 & Ammonia & 13 & 7,84532 & 7,56468 & 0,28064 & 149.239 \\
\hline 10 & Ammonia & 14 & 7,84532 & 7,56405 & 0,28127 & 160.720 \\
\hline 11 & Solar & 10 & 7,84532 & 4,77637 & 3,06895 & $12.142,3$ \\
\hline 12 & Solar & 11 & 7,84532 & 4,77322 & 3,0721 & $13.356,5$ \\
\hline 13 & Solar & 12 & 7,84532 & 4,75136 & 3,09396 & $14.570,7$ \\
\hline 14 & \begin{tabular}{|l|l|} 
Solar \\
\end{tabular} & 13 & 7,84532 & 4,71483 & 3,13049 & \begin{tabular}{|l}
$15.784,9$ \\
\end{tabular} \\
\hline 15 & Solar & 14 & 7,84532 & 4,68131 & 3,16401 & $16.999,2$ \\
\hline 16 & Bensin & 10 & 7,84532 & 6,0936 & 1,75172 & $64.428,8$ \\
\hline 17 & \begin{tabular}{|l|l|} 
Bensin \\
\end{tabular} & 11 & 7,84532 & 6,06127 & 1,78405 & \begin{tabular}{|l|l}
$70.871,3$ \\
\end{tabular} \\
\hline 18 & Bensin & 12 & 7,84532 & 6,03808 & 1,80724 & 77.314 \\
\hline 19 & Benkin & 13 & 7,84532 & 6,01087 & 1,83445 & $83.756,8$ \\
\hline 20 & \begin{tabular}{|l|l|} 
Bensin \\
\end{tabular} & 14 & 7,84532 & 6,00301 & 1,84231 & $90.199,7$ \\
\hline 21 & $\begin{array}{l}\text { Ethylene } \\
\text { Glycol }\end{array}$ & 10 & 7,84532 & 3,53478 & 4,31054 & $1.180,18$ \\
\hline & $\begin{array}{l}\text { Ethylene } \\
\text { Glycel }\end{array}$ & & & & & \\
\hline 22 & \begin{tabular}{|l|} 
Glycol \\
Fttwylom
\end{tabular} & 11 & 7,84532 & 3,51742 & 4,3279 & $1.298,2$ \\
\hline 23 & $\begin{array}{l}\text { Ethylene } \\
\text { Glycol }\end{array}$ & 12 & 7.84532 & $\{43386$ & 444146 & 1416.22 \\
\hline & \begin{tabular}{|l|} 
Ethylene \\
\end{tabular} & & $1,0+0+5,52$ & $J_{2}+5300$ & $4,+11+0$ & $1.410,22$ \\
\hline 24 & Glycol & 13 & 7,84532 & 3,35664 & 4,48868 & $1.534,24$ \\
\hline 25 & $\begin{array}{l}\text { Ethylene } \\
\text { Glycol }\end{array}$ & 14 & .84532 & 3.35029 & 4.49503 & $1.652,26$ \\
\hline
\end{tabular}

Tabel 1 merupakan hasil penelitian analisa profil aliran fluida dan penurunan tekanan pada jenis fluida air, amonia, solar, bensin dan etilen glikol. 
Dari hasil penelitian tersebut terlihat bahwa diantara jenis-jenis fluida tersebut terdapat pressure drop yang bervariasi, dimana pressure drop tertinggi terdapat pada jenis fluida etilen glikol dan pressure drop terendah terdapat pada jenis fluida amonia.

Hasil Analisa Profil Aliran Fluida dan Penurunan Tekanan (Pressure drop) dengan metode simulasi CFD pada jenis fluida Air, Amonia, Solar, Bensin, Etilen glikol

a. Fluida air pada laju alir 14 ton/jam

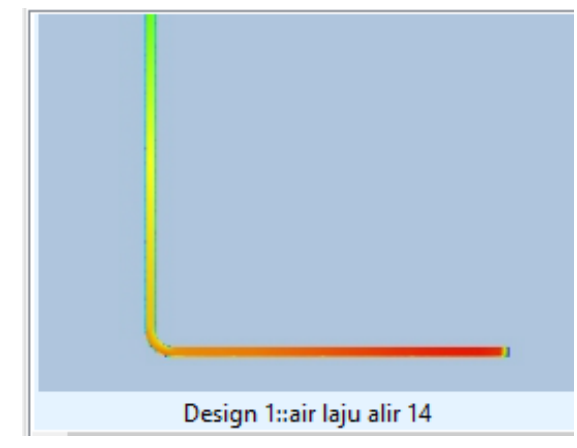

b. Fluida amonia pada laju alir 14 ton/jam

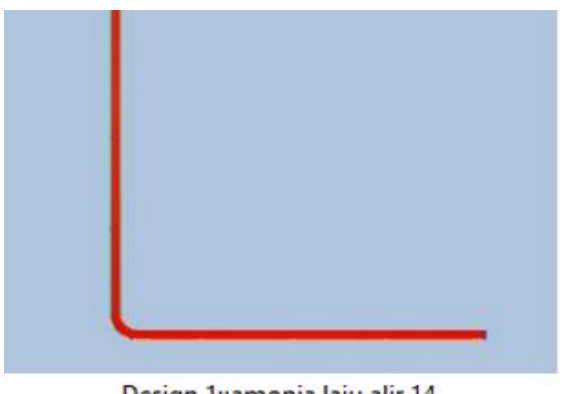

Design 1::amonia laju alir 14 
c. fluida solar pada laju alir 14 ton/jam

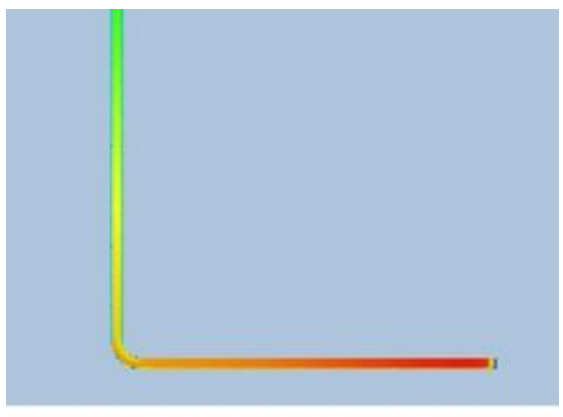

Design 1::solar laju alir 14

d. Fluida bensin pada laju alir 14 ton/jam

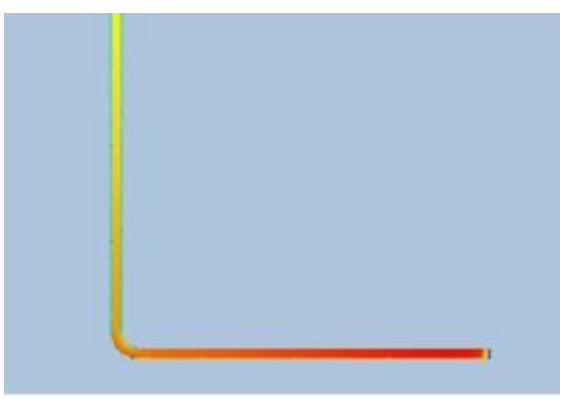

Design 1::bensin laju alir 14

e. Fluida etilen glikol pada laju alir 14 ton/jam

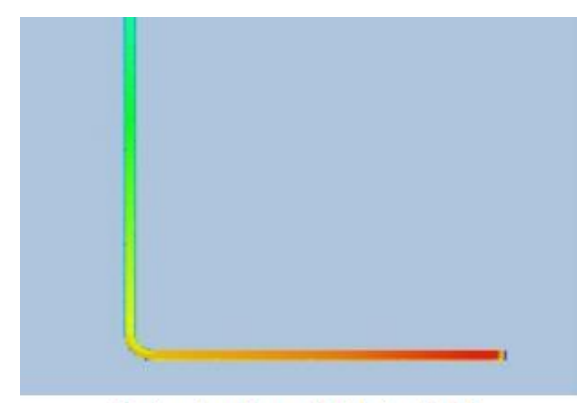

Design 1::etilen glikol laju alir 14

Dari Gambar-gambar di atas dapat dilihat hasil simulasi terhadap profil aliran fluida air, Amonia, Solar, Bensin, dan Etilen glikol dan penurunan tekanan pada pipa dengan software autodesk simulation CFD menunjukkan bahwa terjadi penyebaran tekanan ditandai perubahan warna merah menjadi warna kuning, biru 
dan hijau. Pada tekanan masuk dengan ditandai warna merah memiliki tekanan sebesar 7,845 Bar, akan tetapi perubahan tekanan yang terjadi di dalam pipa tidaklah sama karena pengaruh viskositas dari fluidanya. Warna merah merupakan tekanan tertinggi, selanjutnya diikuti dengan warna orange, kuning, dan hijau. Warna hijau menunjukkan tekanan terendah.

Dari ke lima gambar di atas terlihat bahwa tekanan paling rendah yaitu pada gambar ke enam karena pada gambar ke enam fluida yang digunakan adalah etilen glikol yang mana viskositasnya sangat tinggi yaitu 21,4 sehingga penurunan tekanan yang terjadi di dalam pipa sangatlah tinggi sehingga mengakibatkan tekanan fluida di dalam pipa tersebut sangat rendah. Hal tersebut dapat terlihat dari perubahan warnanya, dimana warna hijau yang merupakan tekanan terendah terdapat hampir mendekati belokan pipa, hal ini terlihat bahwa fluida etilen glikol setelah melewati elbow hampir tidak bisa mengalir lagi.

Kemudian diikuti oleh Gambar ke 3 yang berjenis solar dengan viskositasnya sebesar 2,08 cP. Kemudian diikuti oleh gambar pertama yang fluidanya berjenis air dengan visositas 1,003 cP. Selanjutnya diikuti oleh fluida yang berjenis bensin dengan viskositas 0,392 cP. Dan kemudian diikuti oleh fluida yang berjenis amonia dengan viskositas $0,22 \mathrm{cP}$, pada fluida amonia terlihat bahwa tidak ada perubahan warna sama sekali, seluruh dari pipa berwarna merah hal ini dikarenakan viskositas dari amonia sangat rendah yang mengakibatkan hampir tidak terjadi penurunan tekanan bila dilihat dari gambar yang ke 2, akan tetapi bila kita lihat nilainya maka penurunan tekanannya tetap terjadi tetapi dengan ukuran yang sangat kecil yaitu 0.28127 Bar. Dengan nilai penurunan tekanan yang sangat kecil tersebut maka dari silmulasi gambarnya tidak terlihat adanya fariasi warna seperti pada fluida-fluida lainnya.

Nilai viskositas dari fluida sangat mempengaruhi penurunan tekanan fluida, hal ini sesuai dengan teori yang menyatakan bahwa nilai viskositas suatu 
fluida berbanding lurus dengan penurunan tekanan dari fluida tersebut. Penurunan tekanan yang besar sangat mempengaruhi kinerja suatu pompa untuk mengalirkan suatu fluida dari suatu tempat ke tempat lainnya. Apabila jenis fluida memiliki viskositas yang tinggi, maka tekanan yang dihasilkan dari pompa harus tinggi supaya dapat mengalirkan fluida ke tempat yang diinginkan.

\section{Hasil Analisa Profil Aliran Fluida pada elbow $\mathbf{9 0}^{0}$}

Berikut ini merupakan profil aliran fluida pada belokan $90^{\circ}$

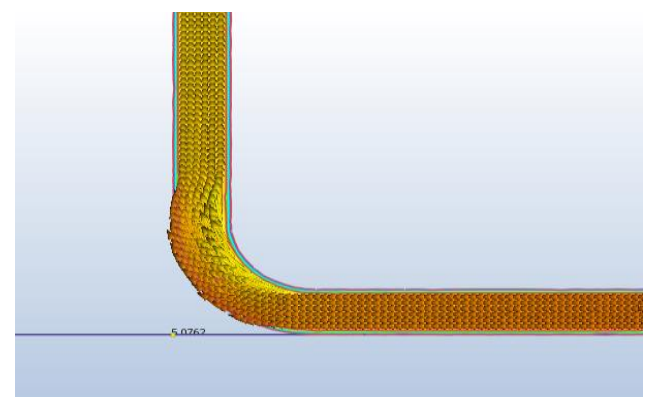

Gambar 4 Profil aliran fluida pada belokan $90^{\circ}$

Dari Gambar 4 terlihat bahwa profil aliran fluida pada elbow mengalami dorongan yang kuat sehingga mengalami benturan yang kuat pada dinding pipa. Dari Gambar di atas dapat dijelaskan bahwa elbow pada pipa sangat mempengaruhi kehilangan tekanan pada sistem perpipaan dikarenakan fluida yang mengalir di dalam pipa mengalami benturan sehingga tekanan fluidanya akan secara otomatis menurun dan memperlambat tekanan dari sutu fluida. Selain itu, adanya elbow dari pipa dapat mengakibatkan terjadinya goncangan pada sistem perpipaan sehingga harus benar-benar diperhatikan ketika merancang suatu sistem perpipaan baik di kehidupan sehari-hari maupun di dalam dunia industri yang dapat mengakibatkan kerugian yang besar seperti rusaknya penyangga karena terbentuknya aliran turbulensi yang besar dikarenakan adanya elbow. 
Penurunan tekanan terjadi akibat adanya turbulensi aliran yang akan menimbulkan gesekan besar pada dinding pipa sehingga akan menimbulkan head losses yang besar.

\section{Pembahasan}

Pada penelitian ini digunakan variasi fluida yang berbeda viskositasnya yaitu Air, amonia, solar, bensin, dan etilen glikol. Dimana viskositasnya secara berurutan yaitu 1,003, 0,22, 2,08, 0,392, dan 21,4. serta divariasikan laju alirannya yaitu 10, 11, 12, 13, 14 Ton/jam. Selanjutnya akan dibahas mengenai hasil yang didapat pada penelitian ini. Dari Tabel 4.1 dapat dilihat dari beberapa jenis fluida diperoleh bahwa penurunan tekanan semakin kecil seiring dengan nilai viskositas fluidanya, apabila nilai viskositasnya semakiin rendah maka penurunan tekanannya semakin kecil, begitu juga sebaliknya jika nilai viskositas fluidanya semakin tinggi mak penurunan tekanan yang terjadi juga semakin besar.

Berdasarkan yang diketahui apabila viskositas suatu fluida tinggi maka penurunan tekanan yang ditimbulkan juga semakin besar. Hal ini dikarenakan fluida yang memiliki viskositas tinggi memiliki tahanan (hambatan) terhadap tekanan geser, tekanan geser merupakan tekanan yang diberikan pada fluida untuk bergerak. Berdasarkan hukum viskositas newton bahwa tekanan geser berbanding lurus dengan viskositas (Sukardjo,2002). Sedangkan mengenai laju aliran, semakin besar laju aliran maka penurunan tekanan juga semakin semakin besar hal ini dapat dijelaskan bahwa apabila aliran dalam pipa besar maka gesekan yang terjadi di sepanjang pipa antara permukaan fluida dengan permukaan bagian dalam pipa semakin besar, sehingga pressure drop yang ditimbulkan semakin besar.

Bilangan Reynold juga dipengaruhi oleh viskositas dan laju alir, apabila viskositasnya tinggi maka bilangan Reynold akan kecil. Apabila laju alirnya tinggi maka bilangan Reynold akan semakin tinggi. Apabila bilangan Reynold 
nya sangat tinggi, maka perlu diperhatikan dalam proses perancangan sistem perpipaan yang dapat mengakibatkan kerugian besar seperti rusaknya penyangga dan bocornya pipa.

\section{Analisa Hubungan Laju Alir Terhadapa Jenis Fluida dan Pressure Drop (Penurunan Tekanan)}

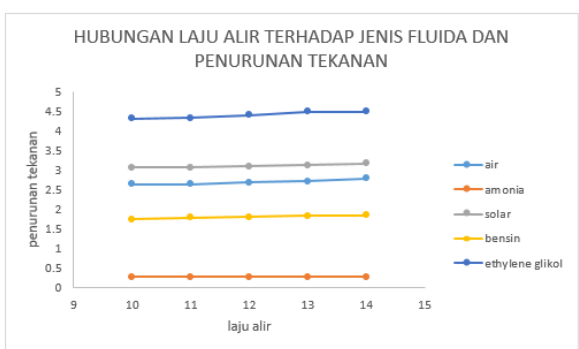

Gambar 5 Hubungan laju alir

Dari Gambar 5 dilihat perbandingan pressure drop dan laju alir pada jenis fluida Air, amonia, solar, bensin, dan etilen glikol dengan autodesk simulation $C F D$. pressure drop tertinggi terdapat pada jenis fluida etilen gikol dengan laju alir 14 ton/jam sebesar 4.49503 bar. Sedangkan pressure drop terendah terdapat pada jenis fluida amonia dengan laju alir 10 ton/jam sebesar 0.27 bar. Hal ini dikarenakan perbedaan viskositas dari jenis fluida, bila viskositasnya tinggi maka pressure drop juga tinggi. Selain itu laju alir juga memengaruhi pressure drop, apabila laju alirnya tinggi maka pressure drop juga tinggi.

\section{Analisa Hubungan Laju Alir Terhadapa Jenis Fluida dan Reynold Number (bilangan reynol)}




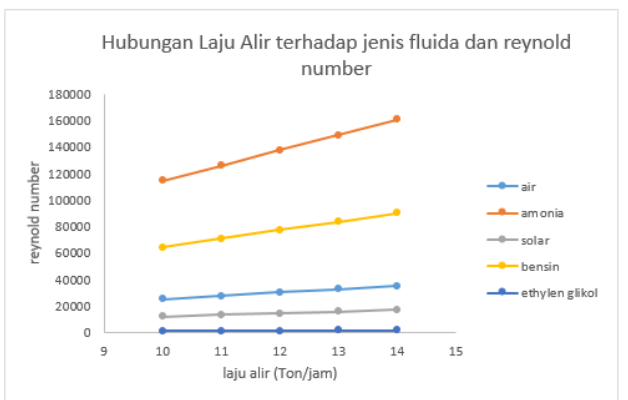

Gambar 6 Perbandingan bilangan Reynold

Dari Gambar 6 dapat dilihat perbandingan reynold number dengan autodesk simulation CFD pada jenis fluida Air, amonia, solar, bensin, dan etilen glikol. Bilangan reynol tertinggi terdapat pada jenis fluida amonia dengan laju alir 14 ton/jam sebesar 160.720. Sedangkan Bilangan reynol terendah terdapat pada jenis fluida etilen glikol dengan laju alir 10 ton/jam sebesar 1.180,18. Hal ini dikarenakan perbedaan viskositas dari jenis fluida, bila viskositasnya tinggi maka bilangan Reynold nya akan sedikit. Selain itu laju alir juga memengaruhi bilangan Reynold, apabila laju alirnya tinggi maka bilangan Reynold nya juga tingi.

Dari Gambar 4.5 terlihat bahwa terdapat dua jenis pola aliran yaitu turbulen dan laminer. Pola aliran laminer terdapat pada jenis fluida etilen glikol, dan pola aliran turbulen terdapat pada jenis fluida air, amonia, solar, dan bensin.

\section{Kesimpulan dan Saran}

Setelah dilakukan analisa profil aliran fluida dan pressure drop dengan autodesk simulation CFD maka didapat beberapa kesimpulan diantaranya sebagai berikut:

1. Hasil simulasi yang dilakukan pada pipa bersambung L dengan variasi jenis fluida dan laju alir dimana semakin besar viskositas dari suatu fluida maka semakin besar penurunan tekanannya dan semakin besar laju alirnya maka semakin besar penurunan tekanannya. 
2. Bilangan Reynold tertinggi terjadi pada jenis fluida amonia dengan laju alir 14 ton/jam yaitu 160.720 dan sedangkan yang tere ndah terjadi pada jenis fluida etilen glikol dengan laju alir 10 ton/Jam yaitu 1.180 ton/jam.

3. Pressure drop terendah yang didapat dari simulasi terjadi pada jenis fluida amonia dengan laju alir 10 ton/Jam sebesar 0,27799 bar, sedangkan pressure drop tertinggi terjadi pada material pipa jenis fluida etilen glikol dengan laju alir 14 ton/Jam sebesar 4,49503 bar.

Untuk pengembangan penelitian ini agar lebih bagus lagi maka penulis memberikan saran untuk kedepannya agar memvariasikan jenis material pada pipa yang digunakan serta memvariasikan bentuk-bentuk pipa yang lainnya.

\section{Daftar Pustaka}

Al-Shemmeri,T.,Engineering Fluid Mechanics. $\underline{\text { http:// bookboon. }}$ com/en/mechanics -ebooks 10 Juni 2012 .

Deslia, Prima. 2011. Laporan Dasar-dasar Proses Kimia I. www.scribd.com. desember 2013. Pekanbaru.

McCabe L Warren, Smith C Julian, and Herriot Peter, 1985. “Operasi Teknik Kimia Jilid 1 .Edisi Keempat.Jakarta: Erlangga.

Miller, J.J. 1978. The inverse of the Freeman-Turky dauble arcsine transformation. American Statistican,32(4), 138.

Sitorus, E. (2016). Pengaruh Panjang Pipa U Bersambung terhadap Pressure Drop Dengan Metode Computational Fluid Dynamic (CFD).

Sukardjo. 2002. Kimia Fisika. Jakarta: Bineka Cipta.

Tipler, Paul A. 1998. Fisika: untuk Sains dan Teknik (terjemahan). Jakarta: Erlangga.

White M, Frank dan Hariandja, Manahan. 1988. Mekanika Fluida (terjemahan). Erlangga, Jakarta. 